\title{
CRITERIA FOR APPOINTMENT OF MEMBERS TO UNIVERSITY COUNCILS IN POLISH PUBLIC HEIS: MANAGEMENT PROFESSIONALIZATION IN THE POLISH ACADEMIA
}

\author{
Ewelina Milewska* ๑ http://orcid.org/0000-0002-3957-1447
}

\begin{abstract}
Background. For many years, the Polish style of managing universities was based on the Humboldtian model of higher education and the assumption of academic self-government that decides in a collegial manner. Simultaneously, Ustawa 2.0 (The Law on Higher Education and Science of 20 July 2018) significantly changed the way of managing universities. The state authorities noticed that the hermetic academic environment must become open toward the socioeconomic sphere, cooperate with it, and enable universities to professionalize their management.
\end{abstract}

Research aims. This article seeks to learn the criteria of appointing members to university councils in Poland from the perspective of Ustawa 2.0 and those people who were directly or indirectly engaged in choosing the councils' members. In the light of this goal, I had to capture the solutions introduced by Ustawa 2.0 from the perspective of changes that occurred in the university management in Poland.

Methodology. I used a mixed methodology to conduct this study. To that end, I analyzed the contents of Ustawa 2.0 and particularly focused on articles about appointing members to the councils. Additionally, I analyzed twenty statutes of Polish universities singled out by the Ministry of Science and Higher Education in the first edition of the competition "Excellence Initiative - Research University." Moreover, I interviewed seven people in university management positions who were engaged in appointing members to university councils (among others, a rector and a vice-rector).

Findings. Although university councils operate in many countries, they are a novelty in the structures of the higher education institution (HEI) management system in Poland. The role and competencies of the councils are broad, and they practically influence how Polish universities operate. The conducted research showed that the appointment of members to the university councils follows the universal rules specified in the Ustawa 2.0 and, partially, in the statutes of universities. The

* Jagiellonian University in Kraków. E-mail: e.milewska@uj.edu.pl. 
law indicates that university council members should be persons respected in the academic environment, who know the mission and values of a given university.

Keywords: higher education in Poland, HEI, Ustawa 2.0, university council.

JEL Codes: H75, I23, I28.

\section{INTRODUCTION}

Polish universities were the subject of many changes and reforms of management. The Act of 20 July 2018 on the Law on Higher Education and Science - called Ustawa 2.0 - is the aftermath of ongoing criticism of the higher education system. The system's most criticized aspects were excessive bureaucratization, improper operation in licensing and accreditation of studies, and the inadequate evaluation of scientific activities. The increasing expenditure on scientific research guarantees the improvement of scientific work's effectiveness in Polish universities. However, some emphasize that institutions must be prepared to achieve strong and lasting effects (Górniak, 2017, pp. 131-132). Works over Ustawa 2.0 and its later implementation were supposed to guarantee such effects. The establishment of university councils and the ensuing new order in HEIs were some of the most important elements of Ustawa 2.0. Such councils are a novelty in the Polish system of science and higher education, and they function in accordance with the provisions of Ustawa 2.0.

The term of office of a university council lasts four years and commences on 1 January of the year following the year in which began the term of office of the university senate (Ustawa 2.0, Art. 21. 1). In Poland, university councils constitute one of the public universities' three authority organs besides the rector and the senate. From the perspective of the Polish science and higher education system, such a situation places the university council high in the hierarchy as evidenced by the scope of their duties and the possibility to monitor university finances, e.g. by giving opinions on schedules of works and expenditures, approving reports about executing those schedules, and approving financial reports. Other tasks of a university council include giving opinions on strategy plans and statute projects, monitoring university management, indicating candidates for the rector's office after hearing opinions from the senate, giving opinions on reports about 
the implementation of the university's strategy, and performing other actions specified in its statute (Ustawa 2.0, Art. 18. 1-2).

The first university council was appointed for a partial term of office and operated between June 2019 and the end of 2020. On 1 January 2021, the second term of office for university councils began. Some highlight that university councils - also referred to as boards of trustees - "constitute the political symbol of changes that occur in the approach to higher education, but they simultaneously are significant organs in the new organization of universities" (Antonowicz, 2018, p. 46). Because university councils are a new organ in the Polish public universities, we know about them very little. We need more time to evaluate the introduced changes both on the state level (by introducing the councils into the university management system) and the university level (good practices, solutions, and the evaluation of cooperation for the university's development).

Until recently, Polish universities were managed by individuals and various collegial organs appointed from members of the academic community (Sułkowski et al., 2019). The participation of outsiders was reduced to a minimum through e.g. advisory boards, which could mostly consult and opine specific endeavors. Another sphere in which external stakeholders indirectly engaged in university activities was the potential employers of future graduates (Bryła, Jurczyk \& Domański, 2013; Melink, Pušnik \& Pavlin, 2014). The introduction of external members to university councils and the clear indication of the need to appoint them was a revolution in the HEIs system, which emphasized the need to open Polish universities for cooperation with various entities from the socioeconomic environment. Therefore, now is the unique time to observe the process of establishing, shaping, and cooperating in the university councils.

The aim of this article is to explore the criteria for appointing university council members in Poland from the perspective of both the provisions of Ustawa 2.0 and that of academic leaders who were directly or indirectly involved in appointment processes. After all, the final selection of persons serving in the councils was the decision of each university and Ustawa 2.0 only introduced the necessity of appointing such an organ. Hence, we must learn about the strategies adopted by the universities and the experiences and motivations of academic leaders who participated directly in the process of selecting and appointing particular members to university councils. While it 
is clear that the university councils' internal members represent the academic community of a given university, the external members may come from the public, non-governmental, or private sector. Thus, we should consider whether universities followed their "interest" when selecting external members and intentionally chose in such a way that all members had a coherent vision or were willing to adopt fundamental assumptions consistent with the mission of a given university already during the formation of the university council.

\section{A NEW SYSTEM OF HIGHER EDUCATION IN POLAND: SEEKING BALANCE BETWEEN CONTINUITY AND CHANGE}

In the twentieth century, the first act that specified the norms for the Polish HEIs was the Act on Academic Institutions of 13 July 1920 (Ustawa o szkołach akademickich). At that time and in the following years, the model of Polish universities' management was based on the Humboldtian university model (Ash, 2006; Antonowicz, 2018, pp. 48-49), according to which the state finances the universities. It was one of the liberal models (Leja, 2011, p. 24) that assumedly gave great autonomy to universities, their employees, and students. The Humboldtian model strived for university independence and allowed for the organization of each HEI consistent with its "inner self." The type of academic self-government in which academic communities collegially decide on how to govern their university developed out of the Humboldtian model. We can indicate such organs of Polish universities as academic senates, faculty councils, or institute councils. Let us remember that members of such collegial organs include academics, representatives of university administration, and students. Therefore, we may state that Polish public universities until recently were governed only by people coming from the direct, inner surrounding of a given university. A major step toward changing HEIs in Poland was the Law on Higher Education of 2005, which attempted to combine academic tradition (the Humboldtian model) with the need to implement changes that arise from the massification of higher education, the impact of globalization on education, growing competition, the increasing impact of broadly understood environment, and the society's pressure on universities (Leja, 2011, pp. 31-34). The transition from a liberal university to an 
entrepreneurial university (Clark, 1983) illustrates the need to stop thinking about universities as a hermetically closed milieu of scientists and begin opening them to the socioeconomic environment.

Many show that in recent years, many reforms of higher education systems in the world relied on the New Public Management paradigm (Broucker, De Wit \& Verhoeven, 2018, p. 2). Over the past seventy years, the Polish HEIs experienced many shifts and reforms (Leja, 2011, pp. 29-31; Kwiek \& Szadkowski, 2018). Under communism, the authorities somewhat controlled the Polish academia, and the ideological pressure from the soviet decisive organs in the area of university management significantly inhibited the creation of particular scholar models in East-Central Europe (Connelly, 2000; Oates-Indruchová, 2008). The beginning of the 1990s marks the regaining of broadly understood freedom by the Polish science, but also the further development of academic oligarchy (Clark, 1983), which relies on a strong hierarchy and prevents decision-making by outsiders to the circle of the "oligarchs," as power remains in the hands of professors. At the same time, the idea of academic democracy - evident in the model of academic self-government - received much criticism. In a nutshell, the criticism highlighted the inefficiency of universities operating in such a model (Antonowicz, 2018, pp. 45-46). Moreover, the 1990s was the time when universities emphasized education and didactics, which followed the increase in the number of students at Polish universities (Kwiek, 2012, p. 641).

Furthermore, the period of transition in Poland was the time of the capitalist system's development in the private sector. We may assume that the 1990s was when the university and the private sector followed their separate paths, while the mutual distrust between the business community and academia was evident, while their "differing views on the proper aims of higher education, can be seen as a contemporary incarnation of an age-old tension between the forces of the idealistic and the pragmatic" (Shaw, 2019, pp. 11-12). Highlighting the separation of these two worlds is important from the perspective of potential intersectoral cooperation, which Ustawa 2.0 partially deems necessary. Of course, it is not true that so far universities avoided cooperation with the private sector completely. They did cooperate - often with great success - but the necessity for such a cooperation was never officially voiced by the state authorities. Thus, we may conclude that university 
councils enable the implementation of intersectoral cooperation by connecting the public and private sectors (Suzdalova et al., 2017).

Over the years, universities became institutions that co-create the knowledge society (Leja, 2011, p. 33). Thus, what is important at the level of cooperation between universities and the economic environment is knowledge and technology transfer (Bekkers \& Freitas, 2008; Teixeira, Veiga \& Fernandes, 2019). The mutual learning of organizations is possible through different channels and tools. Studies show that academic leaders emphasize that academia lags and can learn a lot from business in the field of management (Shaw, 2019, p. 5), hence they should recognize the advantages of collaboration and knowledge transfer. We may assume that these were the assumptions of the authors of Ustawa 2.0, which obliges universities to compose their councils not only of academic community representatives but also representatives from outside the university.

University boards of trustees operate under different rules in many countries. Their distinctive feature is that they include representatives from outside the academic community (Antonowicz, 2018, p. 46). The American model of university governance is market-oriented, unlike the Polish one (Clark, 1983). Boards of trustees of private American universities primarily consist of representatives from the corporate business world. Noteworthy, they create an "inner circle" that influences universities and creates university strategies adjusted to their business needs. Although this network of relationships is not so dense, which allows universities to maintain greater autonomy (Barringer \& Slaughter, 2016, pp. 166-167). It seems that the degree of constructing such networks depends on the intensity and type of relationships between different private sector entities in a given market or country. At the same time, we should remember that introducing "alien members" to universities and allowing them to decide on key issues may lead to a reduction or complete loss of university's autonomy and, consequently, to a change of the university's broader role. At the initial stage of works on Ustawa 2.0, it authors assumed that the university council would mainly consist of socioeconomic environment representatives. However, these plans were reviewed because of the necessity to preserve university autonomy (konstytucjadlanauki.gov.pl 2018). In the end, Ustawa 2.0 did not oblige universities to appoint exclusively private sector representatives as external members. 
On the other hand, the German example of HEIs' reforms (Pritchard, 2006; Allemann-Ghionda, 2010) based on the Bologna model shows that university councils were gradually introduced in specific Länder since 1998. The whole process concluded nearly ten years later when North Rhine-Westphalia implemented the act which enabled creating the HEI councils. In Germany, what shapes university councils are legal acts of a particular Land. Moreover, the councils are not subject to any direct influences from the state. Therefore, there is no single model of their operation in Germany. This model depends on the Land where a given university is located (Stawarczyk, 2018, pp. 78-80). Although university councils operate differently in each Land, we can distinguish fundamental roles and functions they perform in Germany. First, university councils constitute organs responsible for strategic counseling. Moreover, they supervise university authorities' actions, partly on behalf of the state (Mayntz, 2002). University councils in Germany by definition should "bridge" relationships with the society, which starkly distinguishes them from American boards of trustees. The desire to include the social perspective in universities appears as one of the main arguments why university councils were initiated in Germany at all (Stawarczyk, 2018). At the same time, observers of this process emphasize similar risks to those in American universities and indicate that HEIs can be thus infiltrated by private interest groups (Stawarczyk, 2018, pp. 83-84).

\section{METHOD}

This study sought to learn and specify criteria of appointing members to university councils from the perspective of law and particular universities, which selected members for their councils within the framework of their own organizational structure. To accomplish the study's goal, I posed three research questions:

RQ1. What changes in the structure of public universities management in Poland did Ustawa 2.0 introduce and how are the principles concerning the appointment of members to university councils regulated in Polish public universities?

RQ2. What internal strategies did university statutes introduce for appointing members of university councils? 
RQ3. What criteria did universities adopt in selecting internal and external members of university councils?

Similar to other organizations, HEIs also need the examination of organizational changes or organizations themselves, along with analyses of how they operate. However, we must also involve the historical aspect of organizational reality (Rowlinson, 2005). The application of such a perspective allowed me for a broad identification of changes happening in HEIs. Moreover, this approach became a starting point for my research and analysis of the results in the historical context. I decided to use qualitative research methods (Baxter \& Babbie, 2003) to execute the research and thus seek explanations and understanding (Strauss \& Corbin, 1998) of reasons behind the adopted criteria of appointing members to the university councils. To that end, I employed the triangulation of research methods, which allowed me to verify the research questions by using at least two research methods (Denzin, 2017). Moreover, this research approach enabled me to observe the analyzed matter from multiple perspectives and to seek answers to research questions from different sources (research methods used).

First, I analyzed the provisions of the Ustawa 2.0 with regard to those of its provisions that mention the criteria and procedures for the appointment of members of university councils and their duties. Second, I analyzed the contents of twenty university statutes. This method allowed me to learn about internal regulations and individual assumptions of particular universities regarding the appointment of members of university councils and their selection criteria. As the criterion for selecting these specific twenty statutes served results of the first edition of the state competition "Excellence Initiative Excellence - Research University," in which the Polish Ministry of Science and Higher Education distinguished twenty best research universities in Poland. Finally, I conducted interviews with rectors, vice-rectors, and other individuals directly or indirectly involved in the processes of selecting members to the first-term university councils. I selected the respondents with purpose and conducted the interviews between September and December 2019. In total, I conducted seven partially structured interviews. The interviews took from several to several dozen minutes. I obtained consent to record the interviews from five respondents. Next, I transcribed the interviews. Two respondents did not consent to my recording of the interviews. In their case, I noted down their statements during the conversation. Transcripts and notes 
from the interviews allowed me to analyze the collected research material and specify significant quotations.

\section{RESULTS}

I present the research results below and show the degree to which the new model of university management is implemented in Poland in the context of appointing university councils. I begin with the legislator's assumptions (Ustawa 2.0). Next, I present internal regulations of specific universities (their statutes). Finally, I report on the practical experience of academic leaders who participated in or observed the selection of members to university councils. Thus, I will first demonstrate the provisions of Ustawa 2.0. Subsequently, I will introduce the internal regulations of individual universities regarding the appointment of members to university councils. Finally, I will discuss the results of the partially structured interviews.

\section{Ustawa 2.0}

Ustawa 2.0 regulates the functioning of university councils in Poland. Its provisions indicate that a university council may consist of a minimum of seven and a maximum of nine persons. Persons from outside the university must constitute $50 \%$ of all members of the council. Moreover, the council also includes the president of the student self-government (Ustawa 2.0, Art. 19. 1-2). Ustawa 2.0 specifies that the same person may be a member of the council for no more than two consecutive terms. Furthermore, the external member appointed by the academic senate must be the chairperson of the council (Ustawa 2.0, Art. 21. 1). Ustawa 2.0 indicates that the person may become a member of a university council if he or she has: full legal capacity; enjoys full civil rights; has not been convicted of an intentional offense or intentional tax offense under a final and binding judgment; has not been punished by disciplinary action; has graduated from a higher education institution; has not reached the age of 67 by the date of commencement of the term of office (this concerns internal members); did not work for the state security authorities and did not serve in them or cooperate with them in the period of 22 July 1944, to 31 July 1990. Noteworthy, Ustawa 2.0 indicates that membership in a university 
council cannot be combined with serving as an organ of this or any other HEI, membership in another university council, or holding a post in public administration (Ustawa 2.0, Art. 20. 1-7).

\section{STATUTES OF TWENTY RESEARCH UNIVERSITIES DISTINGUISHED IN THE FIRST EDITION OF THE COMPETITION "EXCELLENCE INITIATIVE - RESEARCH UNIVERSITY"}

According to Ustawa 2.0, each public university must prepare and implement new statutes. Thus, all public universities included university councils in their new statutes. The analysis of the statutes of the top twenty research universities in Poland allowed me to determine that only six of them decided to describe the criteria of appointing members to the university councils more broadly than Ustawa 2.0, thus establishing own criteria for the appointment of council members. Table 1 presents the provisions of the statutes of these six universities and lists the criteria that apply to members from the academia (internal ones) and from outside the university (external ones). The universities that decided to provide additional details concerning the criteria of appointing members in their statutes included primarily:

- a specified length of service at a given university, e.g. the AGH University of Science and Technology, the University of Gdańsk, and the University of Silesia indicated ten years of service for internal members while the Silesian University of Technology specified the minimum length of service for external members as ten years and the AGH University of Science and Technology as five years;

- an academic degree required from internal members, e.g. the AGH University of Science and Technology indicated at least a habilitation while the Silesian University of Technology at least a Ph.D.;

- knowledge of the specificity and mission of public universities in the case of external members;

- experience: related to the practical use of research results in industrial, scientific, or service activities; in directing and managing the education process at a university; in leading teams 
that conduct research projects, including international projects; in property administration, human resources management, or knowledge in financial matters; ability to lead research teams that conduct projects financed through national or international competitions (applies to internal members).

Table 1. The criteria for appointing members to university councils based on statutes of six research universities in Poland

\begin{tabular}{|c|c|c|}
\hline $\begin{array}{l}\text { Research } \\
\text { universities } \\
\text { in Poland }\end{array}$ & $\begin{array}{l}\text { Criteria for selecting } \\
\text { members to the university } \\
\text { council (INTERNAL) }\end{array}$ & $\begin{array}{c}\text { Criteria for selecting } \\
\text { members to the university } \\
\text { council (EXTERNAL) }\end{array}$ \\
\hline $\begin{array}{l}\text { AGH University } \\
\text { of Science and } \\
\text { Technology }\end{array}$ & $\begin{array}{l}\text { Art. } 20 \text {, items } 1-7 \text { of the Act } \\
\text { Additionally: A member of the } \\
\text { University Council who is an } \\
\text { employee of the University will } \\
\text { have at least a habilitation, at } \\
\text { least ten years of service at the } \\
\text { AGH University of Science and } \\
\text { Technology, and at least one of } \\
\text { the following experiences: } \\
\text { 1) directing and managing the ed- } \\
\text { ucational process in a university; } \\
\text { 2) managing teams conducting } \\
\text { research projects, including in- } \\
\text { ternational projects; } \\
\text { 3) organizational experience in } \\
\text { property administration, human } \\
\text { resources management, or knowl- } \\
\text { edge in financial matters. }\end{array}$ & $\begin{array}{l}\text { Art. } 20 \text {, items } 1-7 \text { of the Act } \\
\text { Additionally: A member of the } \\
\text { University Council from outside } \\
\text { the academia must have at least } \\
\text { five years of professional expe- } \\
\text { rience in leadership positions } \\
\text { related to business, finance, } \\
\text { legal services, management, or } \\
\text { self-employment and be familiar } \\
\text { with the specificity and mission } \\
\text { of a public university. }\end{array}$ \\
\hline $\begin{array}{l}\text { AGH University } \\
\text { of Science and } \\
\text { Technology }\end{array}$ & $\begin{array}{l}\text { Art. } 20 \text {, items } 1-7 \text { of the Act } \\
\text { Additionally: The University } \\
\text { Council will operate based on the } \\
\text { principles of collegiality, trans- } \\
\text { parency, personal commitment } \\
\text { of its members, with respect for } \\
\text { academic traditions, in accordance } \\
\text { with the law and the statutes } \\
\text { and regulations of the University } \\
\text { Council, and with regard to the } \\
\text { mission and strategy of Warsaw } \\
\text { University of Technology and } \\
\text { the welfare of the University } \\
\text { community. }\end{array}$ & $\begin{array}{l}\text { Art. } 20 \text {, items } 1-7 \text { of the Act } \\
\text { Additionally: The University } \\
\text { Council will operate based on } \\
\text { the principles of collegiality, } \\
\text { transparency, personal com- } \\
\text { mitment of its members, with } \\
\text { respect for academic traditions, } \\
\text { in accordance with the law and } \\
\text { the statutes and regulations } \\
\text { of the University Council, and } \\
\text { with regard to the mission and } \\
\text { strategy of Warsaw University } \\
\text { of Technology and the welfare of } \\
\text { the University community. }\end{array}$ \\
\hline
\end{tabular}




\begin{tabular}{|c|c|c|}
\hline $\begin{array}{l}\text { Silesian University } \\
\text { of Technology }\end{array}$ & $\begin{array}{l}\text { Art. } 20 \text {, items } 1-7 \text { of the Act } \\
\text { Additionally: A member of the } \\
\text { Council from the University } \\
\text { community should have at least } \\
\text { ten years of work experience, a } \\
\text { doctoral degree, and meet at least } \\
\text { one of the following conditions: } \\
\text { 1) experience related to the prac- } \\
\text { tical use of research results in } \\
\text { industrial, scientific, or service } \\
\text { activities; } \\
\text { 2) organizational achievements, } \\
\text { particularly in introducing inno- } \\
\text { vative management procedures, } \\
\text { property administration, and in } \\
\text { the scope of human resources and } \\
\text { financial policies applicable to the } \\
\text { activities of the University; } \\
\text { 3) experience in international } \\
\text { cooperation in a scope relevant } \\
\text { to the activities of the University; } \\
\text { 4) ability to manage research } \\
\text { teams conducting projects funded } \\
\text { through national or international } \\
\text { competitions. }\end{array}$ & $\begin{array}{l}\text { Art. } 20 \text {, items } 1-7 \text { of the Act } \\
\text { Additionally: In addition to the } \\
\text { requirements specified in Art. } \\
20.1-3 \text {, a member of the Council } \\
\text { from outside the academia should: } \\
\text { 1) prove past cooperation with } \\
\text { the University through the stim- } \\
\text { ulation of innovative activity and } \\
\text { professional improvement of staff, } \\
\text { knowledge transfer to economic } \\
\text { practice, didactic process enrich- } \\
\text { ment with practical aspects in } \\
\text { various fields, and the promotion } \\
\text { of achievements in the area of } \\
\text { science, implementations, and } \\
\text { innovations; } \\
2 \text { ) have at least ten years of pro- } \\
\text { fessional experience in positions } \\
\text { related to business, finance, } \\
\text { legal services, management, or } \\
\text { owner supervision, including at } \\
\text { least four years in a managerial } \\
\text { position. }\end{array}$ \\
\hline $\begin{array}{l}\text { The University of } \\
\text { Wrocław }\end{array}$ & $\begin{array}{l}\text { Art. } 20 \text {, items } 1-7 \text { of the Act } \\
\text { Additionally: } 18.1 \text { Members of } \\
\text { the University Council will be } \\
\text { appointed from among persons } \\
\text { particularly qualified to uphold } \\
\text { the values and achieve the objec- } \\
\text { tives mentioned in the preambles } \\
\text { of the Act and the Statutes. }\end{array}$ & $\begin{array}{l}\text { Art. } 20 \text {, items } 1-7 \text { of the Act } \\
\text { Additionally: } 18.1 \text {. The Members } \\
\text { of the University Council will be } \\
\text { appointed from among persons } \\
\text { particularly qualified to uphold } \\
\text { the values and achieve the objec- } \\
\text { tives mentioned in the preambles } \\
\text { of the Act and the Statutes. }\end{array}$ \\
\hline $\begin{array}{l}\text { The University of } \\
\text { Gdańsk }\end{array}$ & $\begin{array}{l}\text { Art. } 20 \text {, items } 1-7 \text { of the Act } \\
\text { Additionally: A person appointed } \\
\text { from the University community } \\
\text { who meets the requirements spec- } \\
\text { ified in Art. } 20 \text { of the Act may } \\
\text { be a member of the University } \\
\text { Council. Moreover, this person } \\
\text { should: } \\
\text { 1) be employed at the University } \\
\text { under a contract of employment or } \\
\text { appointment, on a full-time basis; } \\
\text { 2) have at least ten years of work } \\
\text { experience at the University. }\end{array}$ & Art. 20 , items $1-7$ of the Act \\
\hline
\end{tabular}


The University of Silesia in Katowice
Art. 20, items $1-7$ of the Act Additionally: Candidates for the University Council should have outstanding academic, professional, or organizational achievements. A candidate belonging to the University community should have at least ten years of service at the University.
Art. 20, items 1-7 of the Act

Additionally: Candidates for the University Council should have outstanding academic, professional, or organizational achievements.

Source: own elaboration based on the analysis of twenty statutes of universities distinguished by the Ministry of Science and Higher Education ${ }^{1}$ in the first edition of the state competition "Excellence Initiative - Research University."

Most universities based their statute articles regarding the appointment of university councils on the provisions of Art. 20. 1-7 of Ustawa 2.0: Adam Mickiewicz University in Poznań, Gdańsk University of Technology, the University of Warsaw, Jagiellonian University, Wrocław University of Science and Technology, Wrocław University of Environmental and Life Sciences, Pedagogical University of Cracow, Medical University of Łódź, Medical University of Białystok, Poznań University of Medical Sciences, the University of Łódź, Łódz University of Technology, Nicolaus Copernicus University, Medical University of Gdańsk, Warsaw University of Technology.

\section{Experience of Academic Leaders}

The studied academic leaders stressed that the appointment of university council members was a difficult and demanding task. The former also emphasized the significant role of the university council in the context of university development and strategy planning:

people aware that the university is a temple of wisdom and that this temple should be well governed ... [should] not only react to the present but also analyze the future and prepare ... for what lies ahead (R5).

Moreover, the interviewees emphasized that university council service is a great responsibility so council members should be able to fully engage in its tasks:

\footnotetext{
Since 1 January 2021, the institution operates under the name of Ministry of Education and Science.
} 
The appointment of university council members must be very thorough to ensure completeness in the relatively small, seven- or nine-person assembly functioning in a complicated institution that is a university, which deals with so many areas as research, didactics, HR training, and economy (R1).

The respondents indicated that the broadly understood experience of potential candidates was the main criterion for appointing members to university councils. The selection procedure focused on whether the candidates previously performed any management functions, and if so, whether their actions were effective. In the case of selecting external members to university councils, the essential elements were good knowledge of the business world, international experience, and previous cooperation with universities. Another vital criterion was candidates' competencies and interdisciplinarity:

These are people who represent different options ... Their questions concerning especially the university's cooperation with the socioeconomic environment ... were certainly substantial and aimed to specify the biggest problems we face in terms of the following cooperation fields: science-business, science-industry, and science-university entrepreneurship. I admit they are really competent in this respect. I certainly believe that consulting the university council about these activities is very appropriate and may bring additional positive results in terms of planning strategic or operational actions concerning the matters in question (R4).

Another thing crucial for appointing the members of university councils was the candidates' availability and their knowledge of the public university's mission and management. Some universities decided to appoint representatives of private enterprises or cultural or church institutions earlier associated with the university who identify with their alma mater.

When it comes to external members of the university council, they must understand higher education at least to some extent. They must have broad horizons and time (R1).

In turn, what was also relevant when appointing internal members to a university council were the issues of scientific and didactic work, along with the international experience of candidates. In many cases, people renowned in the academic community and the world of science were appointed to the university councils. Those were the people who 
enjoy high public trust, are open to change, were building the academic community for years, and were previously involved in issues relevant to the particular university. Moreover, some universities decided to appoint administration representatives to university councils. Those are people who know how the university works e.g. in the area of financial, formal, or legal matters.

so that the university council includes also those who feel the university not only from the scientific and didactic side ... I strongly wished these people would fit the expectations of the new act [Ustawa 2.0] in terms of its hard framework, i.e. scientific research, implementations, and cooperation between science and business. But I also wanted that there would be a representative of the university administration present (R5).

In terms of appointing university council members, some universities adopted the strategy of representing scientific disciplines. Due to the limited number of members in university councils, such a strategy was feasible if the university provides education in only a few disciplines.

We decided to represent our university structure in the university council to a little extent... We have four scientific disciplines and we wanted all of them to be represented, and so they are represented (R2).

\section{DISCUSSION}

Examples for the implementation and functioning of university councils indicate that their main task is the supervision of university management and development. Moreover, university councils allow for building strong connections and relationships between universities and different economic sectors (Barringer \& Slaughter, 2016), following the assumption that there is a necessity for knowledge and technology transfer that enables the cooperation of private and public sector entities (Bekkers \& Freitas, 2008). Although university councils operate in many countries around the world, they are a novelty in the Polish university management system.

Polish universities primarily followed the provisions of Ustawa 2.0 and the directives imposed by the state for the selection of council members. The key changes introduced by the legislator included the 
appointment of university councils as university organs alongside the rector and academic senate. In fact, it is a change in the management structure of Polish universities that bases on the introduction to the academic authorities of socioeconomic environment representatives, most often unrelated to higher education. Ustawa 2.0 regulates criteria for appointing university council members in a general manner. It mostly suggests formal and legal solutions such as university council tasks, the number of members, term of office, members' remuneration, and formal restrictions for potential candidates. Moreover, Ustawa 2.0 allows universities to freely select members to university councils without imposing exactly what entities should be their members. Thus, Ustawa 2.0 maintains the universities' autonomy regarding decisions on the councils' final composition (RQ1). Noteworthy, the subject literature foregrounds (Barringer \& Slaughter, 2016) that it is the university that decides who should become an external member of the council, and Ustawa 2.0 does not impose that external university council members should represent the private sector, as is the case in other countries. Thus, as the first term of university councils showed, the external representatives often include local activists, directors of local public institutions, former rectors, representatives of non-governmental organizations, but also entities from the private sector and widely understood business. Therefore, it seems that there currently is no danger of excessive interference of the private sector in the strategy, development, and methods of universities' operation in Poland.

My analysis of the twenty statutes of research universities in Poland revealed that the majority of universities applied - at least at the formal level - exactly the same criteria for appointing its councils' members as those defined in Ustawa 2.0 (RQ1). Only a few universities decided to extend the criteria with inner recommendations regarding the appointment process. This is how we may understand the adoption of such additional criteria for appointing internal university council members as this strategy: the minimum length of service (e.g. ten years); a specific academic title like habilitation; international experience and practice; and scientific, professional, or organizational achievements (RQ2 and RQ3). Moreover, the adoption of such criteria as work experience or a specific academic degree seems to maintain academic oligarchy in university structures. Thanks to such solutions, this may strengthen the oligarchs' position in a given university. The statutes 
analyses indicated that when the universities decided to specify inner regulations, the criteria largely concerned the appointment of internal members from the academic community. The statutes focused much less on external members. In the case of the latter, the most indicated factor was professional experience - which varied depending on the university's type - and the minimum length of service in managerial positions (RQ2 and RQ3). Noteworthy, in the case of both internal and external members, the statutes indicated that the candidates should understand the values, mission, and strategy of public universities.

Allow me to also foreground that some universities adopted various informal strategies of appointing members that were not explicitly expressed in university statutes, but which emerged during the interviews with academic leaders. One of these strategies was the appointment of different academic disciplines representatives as internal members so that each discipline had a representative on the council. Another common practice was the appointment of people working in university administration as internal council members. Such decisions appeared as motivated by the candidates' excellent knowledge of formal, legal, and financial issues concerning the university (RQ2).

The interviews with academic leaders revealed the crucial role of university councils in the academic governance process, hence the interviewees remarked that the selection of members was thoughtful and thorough. In the appointment of internal members to the council, the selection method involved criteria such as experience in management positions, good knowledge of the university's operational mechanisms, and recognition in the academic community (RQ3). The interviews also showed that the provisions of Ustawa 2.0 always accompanied the appointment of university council members. Discussions about the appointment focused on candidates' international experience, which applied both to internal and external candidates (RQ3). The key assumptions and goals of Ustawa 2.0 include the internationalization of universities, the new model of effective university management, changes in the educational model, increased funding, linking potentials, and the sustainable development of universities (RQ1). Therefore, when appointing candidates, it was essential to indicate their potential and abilities regarding the introduction of changes consistent with the legislator's assumptions. However, it seems that from the perspective of the university, the appointment of internal members to the councils was another necessary decision similar to the selection of members 
for other collegial university organs. At the same time, the interviews emphasized the prestige associated with the appointment of an employee to the university council. From the universities' perspective, the appointment of external members was much more difficult because this matter involved the decision of who should enter the university and who should gain access to the knowledge about the university's internal affairs, which had been so far hidden from the outside world. We may assume that the universities were very cautious and adopted quite universal appointment criteria, whose fulfillment was supposed to comply with the Ustawa 2.0 (RQ2 and RQ1).

\section{CONCLUSIONS}

Just before the publication of Ustawa 2.0, the university councils were described as such that "allow observing the university's strategy from another perspective, opening the hermetic academic environment to the socioeconomic environment, and offering a chance to professionalize the [university] management" (konstytucjadlanauki.gov.pl 2018). The last fragment deserves special attention as it refers to the professionalization of university management. We may ask whether the Polish universities already underwent the transformation described several years ago as the university's shift from the "republic of scholars" to a "stakeholder organization" (Bleiklie \& Kogan, 2007, p. 477). Apparently, the transformation process in the Polish higher education occurred with a significant delay of at least several years when compared to similar reforms in other European countries.

As the American example shows, university councils have a much longer history and tradition than the concept of New Public Management (Stawarczyk, 2018, p. 78), but this example indicates the orientation of universities toward an administration akin to private sector management. University councils in Poland are a transfer of this idea onto the grounds of public university management while striving for the professionalization of management and continuous subordination of university's activities to the rules of efficiency. The conception of New Public Management and the term "new managerialism" refer to a situation when public sector organizations - including public universities - adopt organizational forms, technologies, management practices, and values frequently found in the private sector (Deem, 
1998, p. 47). Therefore, incorporating university councils from the legislator's level into university management structure is a step that brings the latter closer to the forms widely practiced by the business world (Veiga, Magalhães \& Amaral, 2015, pp. 398-399). For instance, university councils are like supervisory boards in the private sector. At the same time, we may assume that the appointment of university councils in Poland is an indirect result of the phenomenon called "boardism" (Veiga, Magalhães \& Amaral, 2015, p. 399). The result of this phenomenon is that over the years and after seeing the need to increase the effectiveness of universities, control over the implementation of their mission - previously performed by the state administration - shifted toward the evaluation of universities' effects. This means that universities in a way began to function as corporate actors (Antonowicz, 2018, pp. 51-52; qtd. after Amaral et al., 2003; Mayntz, 2002) strictly accountable for the effects of their work.

At this point, we should consider directions of further research in the area of university councils in Poland. We should remember that although university councils formally operate in the structures of all public universities in Poland, we cannot explicitly assess how these activities affect their functioning and whether the activities actually contribute to the improvement and professionalization of management. Simultaneously, the appointment of members to the councils strictly follows the criteria dictated by the provisions of Ustawa 2.0. However, each university can freely select individual council members. Therefore, I deem it right to study these areas in the future so as to determine the effectiveness and relevance of the actions the university councils undertake. We should also conduct research to identify the impact and changes introduced in management structure by the establishment of university councils both in the short and long term. Moreover, as shows recent research on the participation of women and men in university authorities in Poland (Sułkowski et al., 2019), gender balance could be one of the possible future criteria in the selection of university council members and other collegiate bodies in the academia.

Thus, it appears that the universities may adopt - now and in the future - different strategies for appointing members to their councils. Only the universities decide whether they utilize new cooperation opportunities and the potential of external partners. After all, the essence of good cooperation is mutual understanding, learning from each other, the ability to reciprocally transfer knowledge, and openness 
to look in the same direction. However, good cooperation also includes the ability to admit a mistake made by one of the parties and remaining open to new - and perhaps better and more effective - activities. On the one hand, university councils form a connective tissue between universities and the broadly understood socioeconomic environment, which provides an opportunity for cooperation between the public and private sectors. On the other hand, the councils became elements of university structures, which means that the purpose of cooperation of the council members is the implementation of university missions and striving to increase the effectiveness and development of Polish science. At the same time, the abovementioned restraint of university authorities in appointing external members to the university councils suggests that Polish HEIs do not fully understand or simply do not want a direct link between academia and the business world. Hence, I believe that although Ustawa 2.0 envisions the importance of university councils' function and assigns to them many responsible roles, the practice and appointment of entities from outside the private sector suggests that - marked with rich history and tradition of academic independence - Polish universities remain reluctant to allow for a radical interference of external stakeholders in university management.

The criteria for the appointment of university council members described in this article is mostly public knowledge (Sanchez, 2001, pp. 161-162) formally stated in relevant documents. At the same time, we may assume that some criteria were included indirectly in the decision-making process of council members appointment, even if these were not explicitly voiced in the documents or expressed during interviews with academic leaders. What I mean are informal and perhaps unconscious organizational behaviors that directly result from many years of tradition, commonly used and practiced solutions, unwritten norms and rules of functioning in the academic environment, or broadly understood organizational culture of a given university. Future research should scrutinize such indirect selection criteria, which were not included in the documents but which certainly constitute an inherent part of authorities' decision-making process when selecting candidates for important positions at the university. 


\section{REFERENCES}

Allemann-Ghionda, C. (2010). Reforma szkolnictwa wyższego w Niemczech: Akademickie przedsiębiorstwo w budowie. Nauka i Szkolnictwo Wyższe, 1-2(35-36), 125-142.

Amaral, A., Meek, V.L., Larsen, I.M. \& Lars, W. (Eds.) (2003). The Higher Education Managerial Revolution? Vol. 3. New York: Springer Science \& Business Media.

Antonowicz, D. (2018). Rady powiernicze w szkolnictwie wyższym. Nauka i Szkolnictwo Wyższe, 1(51), 45-68.

Ash, M.G. (2006). Bachelor of what, master of whom? The Humboldt myth and historical transformations of higher education in German-speaking Europe and the US. European Journal of Education, 41(2), 245-267.

Barringer, S.N. \& Slaughter, S. (2016). University trustees and the entrepreneurial university: Inner circles, interlocks, and exchanges. In: Higher Education, Stratification, and Workforce Development (pp. 151-171). Cham: Springer.

Baxter, L.A. \& Babbie, E.R. (2003). The Basics of Communication Research. Wadsworth: Cengage Learning.

Bekkers, R., \& Freitas, I.M.B. (2008). Analysing knowledge transfer channels between universities and industry: To what degree do sectors also matter? Research Policy, 37(10), 1837-1853.

Bleiklie, I. \& Kogan, M. (2007). Organization and governance of universities. Higher Education Policy, 20(4), 477-493.

Broucker, B., De Wit, K. \& Verhoeven, J.C. (2018). Higher education for public value: Taking the debate beyond New Public Management. Higher Education Research \& Development, 37(2), 227-240.

Bryła, P., Jurczyk, T. \& Domański, T. (2013). Korzyści współpracy uczelni wyższych $\mathrm{z}$ otoczeniem gospodarczym - próba typologii (Benefits of co-operation of universities with their business environment-A classification attempt). Marketing i Rynek, 4, 14-19.

Clark, B.R. (1983). The Higher Education System: Academic Organization in Cross-National Perspective. Berkeley: University of California Press.

Connelly, J. (2000). The sovietization of higher education in the Czech Lands, East Germany, and Poland during the Stalinist period, 1948-1954. In: Academia in Upheaval: Origins, Transfers, and Transformations of the Communist Academic Regime in Russia and East Central Europe (pp. 141-177). Westport, Conn.: Bergin \& Garvey. 
Deem, R. (1998). 'New managerialism' and higher education: The management of performances and cultures in universities in the United Kingdom. International Studies in Sociology of Education, 8(1), 47-70.

Denzin, N.K. (2017). Sociological Methods: A Sourcebook. New York: Routledge.

Górniak, J. (2017). Ustawa 2.0: Partycypacyjny model istotnej zmiany regulacyjnej. Nauka i Szkolnictwo Wyższe, 2(50), 129-146.

Konstytucja dla nauki (2018). Rada uczelni, czyli jak profesjonalnie zarządzać uczelniami, https://konstytucjadlanauki.gov.pl/rada-uczelni-czyli-jak-profesjonalnie-zarzadzac-uczelniami (Accessed: 27 $7^{\text {th }}$ December 2020).

Kwiek, M. (2012). Changing higher education policies: From the deinstitutionalization to the reinstitutionalization of the research mission in Polish universities. Science and Public Policy, 39(5), 641-654.

Kwiek, M. \& Szadkowski, K. (2018). Higher education systems and institutions, Poland. In: P. Teixeira \& J. Shin (Eds.) Encyclopedia of International Higher Education Systems and Institutions (pp. 1-9). Dordrecht: Springer. https:// doi.org/10.1007/978-94-017-9553-1_375-1.

Leja, K. (2011). Koncepcje zarzadzania wspótczesnym uniwersytetem. Gdańsk: Wydawnictwo Politechniki Gdańskiej.

Mayntz, R. (2002). University councils: An institutional innovation in German Universities. European Journal of Education, 37(1), 21-28.

Melink, M., Pušnik, T. \& Pavlin, S. (2014). Emerging Modes of Cooperation between Private Enterprises and Universities-Insights of European Enterprises and Employers Organisations. University of Ljubljana, Faculty of Social Sciences.

Oates-Indruchová, L. (2008). The limits of thought? The regulatory framework of social sciences and humanities in Czechoslovakia (1968-1989). Europe-Asia Studies, 60(10), 1767-1782.

Pritchard, R. (2006). Trends in the restructuring of German universities. Comparative Education Review, 50(1), 90-112.

Rowlinson, M. (2005). Historical research methods. In: Research in Organizations: Foundations and Methods of Inquiry (pp. 295-312). San Francisco, CA: Berett-Kohler Publishers.

Sanchez, R. (2001). Knowledge Management and Organizational Competence (Vol. 21). R. Sanchez (Ed.). Oxford: Oxford University Press.

Shaw, M.A. (2019). Public accountability versus academic independence: tensions of public higher education governance in Poland. Studies in Higher Education, 44(12), 2235-2248.

Stawarczyk, F.M. (2018). Rady uczelni jako nowy organ władzy w szkołach wyższych. Przykład Niemiec. Folia Pomeranae Universitatis Technologiae Stetinensis. Oeconomica, 93, 77-86. 
Strauss, A. \& Corbin, J. (1998). Basics of Qualitative Research Techniques. Thousand Oaks, CA: Sage publications.

Sułkowski, Ł., Bogacz-Wojtanowska, E., Wrona, S., Jędrzejczyk-Kozioł, A., Góral, E. \& Mormul, K. (2019). Unsustainable power distribution? Women leaders in Polish academia. Economics and Sociology, 12(3), 162-180.

Suzdalova, M.A., Lizunkov, V.G., Malushko, E., Sytina, N. \& Medvedev, V. (2017). Innovative forms of partnership in development and implementation of university-business cooperation. The European Proceedings of Social \& Behavioural Sciences (EpSBS). Vol. 19: Lifelong Wellbeing in the World (WELLSO 2016). Nicosia, 2017, 192016, 450-455.

Teixeira, S.J., Veiga, P.M. \& Fernandes, C.A. (2019). The knowledge transfer and cooperation between universities and enterprises. Knowledge Management Research \& Practice, 17(4), 449-460.

Ustawa z dnia 13 lipca 1920 roku o szkołach akademickich, Dz.U. 1920, No. 72 item 494.

Ustawa z dnia 20 lipca 2018 roku - Prawo o szkolnictwie wyższym i nauce, Dz.U. 2018 item 1668.

Veiga, A., Magalhães, A. \& Amaral, A. (2015). From collegial governance to Boardism: Reconfiguring governance in higher education. In: The Palgrave international handbook of higher education policy and governance (pp. 398-416). London: Palgrave Macmillan.

\title{
KRYTERIA WYBORU CZKONKÓW DO RAD UCZELNI W POLSKICH UCZELNIACH PUBLICZNYCH, CZYLI O POGONI ZA PROFESJONALIZACJA ZARZĄDZANIA W POLSKIEJ AKADEMII
}

\begin{abstract}
Abstrakt
Tło. Przez wiele lat polski model zarządzania szkołami wyższymi oparty był na koncepcjach uniwersytetu humboldtowskiego i bazował na założeniach samorząu akademickiego, w którym decyzje podejmowane były w sposób kolegialny. Jednocześnie Ustawa 2.0 wprowadziła znaczące zmiany w sposobie zarządzania uczelniami. Dostrzeżono konieczność współpracy i otwarcia do tej pory hermetycznego środowiska akademickiego na otoczenie społeczno-gospodarcze i umożliwienia uczelniom profesjonalizacji zarządzania.
\end{abstract}


Cele badawcze. Celem artykułu jest poznanie kryteriów wyboru członków do rad uczelni w Polsce zarówno z perspektywy zapisów nowej ustawy Prawo o szkolnictwie wyższym i nauce z 20 lipca 2018 roku, jak i z perspektywy osób, które były bezpośrednio lub pośrednio zaangażowane w wybór członków do rad uczelni. Ważne z perspektywy wskazanego wyżej celu było uchwycenie wprowadzonych w ustawie rozwiązań z perspektywy zmian, jakie nastapiły w systemie zarządzania szkołami wyższymi w Polsce.

Metodologia. W celu realizacji badań zdecydowano o zastosowaniu metodologii mieszanej. Dokonano analizy treści zapisów ustawy, zwracając szczególną uwagę na zapisy dotyczace powoływania członków do rad uczelni. Dodatkowo analizie poddano dwadzieścia statutów polskich uczelni, które zostały wyróżnione przez Ministerstwo Nauki i Szkolnictwa Wyższego w pierwszej edycji konkursu „Inicjatywa doskonałości - uczelnia badawcza”. Ponadto przeprowadzono siedem wywiadów z osobami na stanowiskach zarządczych uczelni (między innymi: rektor, prorektor), które były zaangażowane w proces wyboru członków rad uczelni.

Kluczowe wnioski. Choć rady uczelni działają w wielu krajach świata, to w Polsce stanowią nowość $\mathrm{w}$ strukturze systemu zarządzania instytucjami szkolnictwa wyższego. Ich rola i zakres kompetencji sa bardzo szerokie i realnie wpływają na funkcjonowanie uczelni w Polsce. Przeprowadzone badania wskazały, że wybór członków do rad uczelni odbywa się w Polsce zgodnie z uniwersalnymi zasadami określonymi w ustawie, a także częściowo w statutach uczelni. Wskazuje się, że członkami rady powinny być osoby szanowane w środowisku akademickim, mające duże doświadczenie w skutecznym zarządzaniu uczelnią oraz doświadczenie międzynarodowe, znające misję i wartości uczelni.

Słowa kluczowe: szkolnictwo wyższe w Polsce, HEI, ustawa 2.0, rada uczelni. 